\title{
Iconographic Variations of St. Eustace Hunting Composition in the Medieval Georgian and French Sculpture
}

\section{Introduction}

7 he theme of hunting occupies an important place in a diverse icono1 graphic repertoire of relief sculpture in the medieval Christian art. Hunting compositions of St. Eustace were very popular both in the Eastern and Western Christian arts.

We find relief scenes with images of hunter-horsemen in different forms and interpretations almost every century from VI-VII to XVI centuries in Georgia. We have a "typical hunting" in Georgian Christian art - a hunter and its victim, which is mainly represented in St. Eustace Placida's compositions. In addition, we also meet compositions, where a hunter is depicted in an atypical context, for example, in Oshki, Bagrati, Tkoba-Erdi, Sadgeri we have an image of a hunter-archer. In this case, the task of the study is also to determine the content of the compositions and their meaning.

Above mentioned themes are found in the Christian art of the West Europe, namely of France, in XII-XVI centuries. But here, along with Placida's hunting, a plot of St. Hubert's hunting is also relevant. The scene of the vision of Hubert narrated in literary sources is similar to that of the vision of St. Eustace. Iconographic schemes of the compositions depicted on the cathedrals are also analogous, with slight differences.

It is worth of note that various approaches have been formed in the artistic and stylistic resolution of the compositions of St. Eustace due to different historical conditions and local traditions.

1 This work was supported by the Shota Rustaveli National Science Foundation (SRNSF) [Grant \#PhD_F_17_82]. 


\section{History of the Study}

Although researchers have never aimed to study St. Eustace and St. Hubert from a unified point of view, observations on this issue, collection of materials and working out of separate issues have a long history. Both Georgian and Foreign scientists were interested in St. Eustace compositions at different times. Among them Natela Aladashvili², Kitty Machabeli ${ }^{3}$, Marika Didebulidze $^{4}$, Tamar Dadiani, Ekaterine Kvachatadze, Tamar Khundadze ${ }^{5}$, Saltykov $^{6}$, Nicole Thierry ${ }^{7}$ (It is Nicole Thierry who mentions themes of St. Hubert in relation to St. Eustace), Tania Velmans ${ }^{8}$, Anita Coumoussi ${ }^{9}$ and others should be mentioned. The article is based on the scientific works of various researchers. Their reflections reinforce our considerations and make the research more profound.

Research methodology used in the article comprises stylistic and comparative analysis of literary sources. The study could be significantly enriched by means of comparative and stylistic methods of Georgian and French hunting scenes.

Hunting scenes of St. Eustace and St. Hubert existing in the medieval France (XII-XVI) are gathered in the article. Found material is considered in relation to Placida's hunting scenes spread in Christian art. The objective of the research is to determine the connection between the plots of

2 Аладашвили Н., Монументальная скульптура Грузии. Сюжетные рельефы V-XI веков, Искусство, 1977.

3 Machabeli K., Georgian Stone Crosses, Tb., 1988;

4 Didebulidze M. "The Vision of St. Eustace” in Medieval Georgian Art, Literatura da Khelovneba, N2, 1990, p. 197-206.

5 Dadiani T., Kvachatadze E., Khundadze T., Medieval Georgian Sculpture, George Chubinashvili National Research Centre for Georgian Art History and Heritage Preservation, Tb., 2017.

6 Салтыков А., Видение св. Евстафия Плакиди, рельефные иконы из Цебелды, Искусство христианского мира, Москва1996.

7 Thierry N., Un problem de continuitè ou de rupture. La Cappadoce entre Rome, Byzance et les Arabes, Comptes rendus des séances de l'Académie des Inscriptions et Belles-Lettres, 121 année, N1, 1977, pp. 98-145.

8 Velmans T., Léglise de Zenobani et le thème de la Vision de Saint Eustache en Géorgie, Cahiers Archeologiques, Picard, 1985, pp.19-49.

9 Coumoussi A., Une representation rare de la vision de Saint Eustache dans une église grecque du XIIIe siècle, Cahiers Archeologiques, Picard, 1985, pp.51-60. 
St. Eustace and St. Hubert. We will try to group up similar compositions, study the content, symbolics, conduct artistic and stylistic analysis and identify iconographic schemes and peculiarities.

\section{Hagiography of Saint Eustace and Saint Hubert}

Information about St. Eustace in Georgian sources was preserved in the Ancient Metaphrastic Collection "Readings from September"10, which is based upon the primary sources of translation from Greek performed by Ekvtime and Giorgi Mtatsmindelebi, Davit Tbeli, Stephane Sananoisdze, Arseni, Ioane Petritsi etc ${ }^{11}$.

The primary sources on the biography of St. Eustace in Western European Christianity are narrated in the work of Jacobus da Voragine - "Golden Legend" (XIII). ${ }^{12}$ The content of St. Eustace literary source given here coincides with the content of the primary source spread in Georgia.

As for the primary sources of the life of French Saint Hubert, his biographic data are found in the work by the French hagiographer Jonas of Orleans (VIII-IX c.). Two manuscripts tell us about Hubert's life. The first dates back to the IX century, and the second to the XI c. These two well known literary sources about St. Hubert's life were collected and included in "Acts of Saints" (Acta Sanctorum), in the chapter of November ${ }^{13}$ (as the 3 November is St. Hubert's Remembrance Day), by missionary Jean-Pierre Smith in XIX. Hagiographic information preserved on Hubert's life is included in Bibliotheca Hagiographica Latina ${ }^{14}$.

According to information told in the Ancient Metaphrastic Collection "Readings from September"15, in the II century Placida, a distinguished warlord, faithful stratilat of Trajan, the Emperor of Rome, converted to

10 Ancient Metaphrastic Collection, Readings from September, Martyrdom of Saints Eustace and Theophiste and of Their Children [224v], Metsniereba, 1986.

11 Ibidem, p. 3.

12 La légende Dorée, Traduite en Français par L'abbé J.B.M. Roze, Édouard Rouveyre, Éditeur, Paris, MDCCCII, 2004.

13 S. Baleau, Les sources de l'histoire de Liège au Moyen Age, Etude critique, T. I, Bruxelles, 1903, pp. 40-45.

14 Bibliotheca Hagiographica Latina, Soc II Bollandiani, Bruxelles, 1911.

15 Ancient Metaphrastic Collection, op.cit., p. 365. 
Christianity after a miracle happened during the hunting. The horseman followed a deer, which took him to the top of a mountain, and suddenly the cross brightened between the antlers of the deer and the pagan layman heard the voice of God: "Placida, why are you pursuing me? ${ }^{16}$ I am Jesus Christ who gave birth to everything from nothing and created a man with my own hand... And again restored him, destroyed with sin..." ${ }^{17}$. After this vision spiritual transformation took place in the life of the warlord. He was baptized together with his family, then patently endured his life, full of trials and persecution, and then passed away as a martyr. He was tortured in a "brazen bull" together with his family ${ }^{18}$.

Judged by information preserved in the literary sources, the plot of the vision of St. Hubert is similar to the plot of Placida's life. According to Maurice Denis ${ }^{19}$, he is thought as a patron saint of hunters. In Sylvain Baleau's words ${ }^{20}$, he lived in the VII-VIII centuries. The formation of his cult, as the patron saint of hunters, was associated with his hobby. It should be noted, that Louis I the Pious (778-840), King of Franks and Holy Roman Emperor, who used to hunt in Ardennes was a follower of Saint Hubert and faithful to him. He announced November 3 the day of great hunting. In the descriptions of XI century the connection between Hubert's vision and the forest hill in Ardennes, which is on the border with South Belgium, and partially borders France and Luxemburg, is mentioned. Just on this border St. Hubert's cult was originated and from here spread in West European art (England, Germany, Belgium and Netherlands). ${ }^{21}$

According to Brian Daniel Starr, ${ }^{22}$ the life of St. Hubert (656-727), Bishop of Liege, was associated with the period of existence of state of Franks, and his motherland was "Austrasia" which covered North-East regions of France, as well as Belgium, Netherlands and west territories of Germany. ${ }^{23}$

\footnotetext{
16 Ibidem, 365.

17 Didebulidze M., op.cit., p. 198.

18 Ancient Metaphrastic Collection, op.cit. p. 365.

19 M. Denis, op.cit. ,p. 40-41.

20 S. Baleau, op.cit., 1903.

21 Biographie nationale, publiée par l' Académie royale des sciences, des letters et des Beaux-arts de Belgique, IX, pp. Bruxelles, 1897, p. 591.

22 B.D. Starr, Dictionary of Saints, 2013, pp. 199.

23 Ch. Oman, The Dark Ages 476-918, London 1914, pp. 111-128.
} 
Saint's life is also closely connected with mentioned regions: he was born in France ${ }^{24}$, Aquitania, which once had been the province of Roman Empire and in 1137 was annexed by France. Hubert, son of Duke Bernard, was a politic figure as well, and played even the role of diplomat. Perhaps, that's why the life of this saint became relevant in medieval art. ${ }^{25}$

According to legend ${ }^{26}$, Hubert was hunting with his horse and dog in Ardennes forest on Good Friday. While hunting, he saw crucified Christ between the antlers of a white deer, who called him to the spiritual life and discipleship of Saint Lambert. In Hubert's vision white is a symbol of purity and intensifies miraculousness. After theophany (in contrast to martyrdom of St. Eustace Placida), he left worldly life and embarked on the path of spiritual life, went to the court of Roman Emperor and became Lambert's spiritual son. He was consecrated as Bishop of Liege, and after the death of St. Lambert the Pope chose Hubert, and soon he became the bishop of Maastricht. During the pastorship, he fought against pagan cults and Christianized pagan churches of Odin (the supreme God in the mythical system of ancient Germans, a leader of the Norse Pantheon) ${ }^{27}$.

Hunting of St. Hubert on Good Friday acquires sacral meaning, and the basis of the image of crucified God between the antlers of deer might proceed from it. White deer takes on special significance. It is a symbol of kind beginning in every culture and considered a symbol of life, fertility and renewal. Celts particularly revered a white deer, which they considered as a mystical animal of supernatural power. Moreover, deer antlers were perceived as the sun rays. It was considered as a mediator between man and God, and its branched antlers were associated with the Tree of Life. As it is known, deer antlers have the ability to revive and renew. In the Celts' imagination, tree branches are also able to be covered with new leaves. Deer antlers were associated to tree branches and this latter was the holiest plant for them. Their God Cernunnos was connected to the cycle of the awakening of nature. It was expressed in the visual art either in the form of branched antlers of deer, or deer, or bull. As for inhabitants of prehistoric Gaul, they had worshiped

\footnotetext{
24 M. Denis, la Légende de Saint Hubert 1896-1897, Paris, c1999, pp. 39.

25 Ibidem, p. 40.

26 Ibidem.

27 Ibidem.
} 
deer before the arrival of the Celts. They called deer antlers a crown and perceived them as a symbol of strength. Deer eventually acquired human image in their faith and was given a name Cernunnos ${ }^{28}$.

Thus, as we see, deer cult of pre-Christian epoch was Christianized both in Georgia and religious beliefs of other countries. The important episode of the lives of Placida and Hubert is connected to deer hunting, which became the favorite topic for the Christian visual art.

\section{Hunting Scene's and Deer's Symbolic}

According to Irma Mamasakhlisi ${ }^{29}$, Zoomorphic thematic takes its origin in the middle of east and Central Asia's art ${ }^{30}$. In Georgian folklore, the deer and the Caucasian ibex have supernatural power. They often appear as connection to the divine world. King Parnavaz - the king of Kartli, found treasure during hunting on the deer. In the imagination of the Caucasian people, deer horns take a huge place; here it is believed to be the symbol of the tree of life ${ }^{31}$. The Christian symbolism of the medieval Georgian Christian art begins with a new sense of pagan forms. In the early Christian art, the spring-drinking deer is used to illustrate the 41 psalm. This hymn is traditionally celebrated on the holy night of Easter. In this context, deer was a face symbol of a man who is preparing for baptism ${ }^{32}$.

Moreover, deer antlers were perceived as the sun rays. It was considered as a mediator between man and God, and its branched antlers were associated with the Tree of Life ${ }^{33}$.

According to Elashvili, Abzianidze ${ }^{34}$, the deer is associated with the sunrise, the light, the purity, the revival. The Ox-deer is an emblem of abundance. His branching horns represent the "tree of life"; changing horns repre-

28 Mamasakhlisi I., The Cult of a Deer in the Culture of Caucasian Peoples, Caucasiological Papers N5, Institute of Caucasology, Tb., 2013, pp. 285-286.

29 Ibidem, pp. 285-286.

30 Ibidem, p. 285.

31 Ibidem., p. 287.

32 Ibidem, p. 289.

33 Ibidem, p. 285.

34 Z. Abzianidze, K. Elashvili, Illustrated Encyclopedia of Symbols, Vol. II, Bakmi, 2006, pp. 94-95. 
sent long living, refers to the renewal. Deer is a guide of magic fairy tales and myths. E.g: The ancient Greek myth where the goddess of hunting, Artemida turns hunter-oqteon into a deer, who had witnessed her during bathing, The same is in Georgian mythology, the goddess of hunting Dali is considered to be the protector of the deer, taking the face of deer from time to time herself ${ }^{35}$.

The long tradition of hunting in Georgia has been confirmed by numerous historical data, ethnographic material, things (for example, weapons) associated with hunting, remained from the era of the Eneolithic. In addition, the oldest Caucasian art samples are characterized by hunting motives, and images of wild animals constitute its main topic ${ }^{36}$. According to Elene Virsaladze's research, angel of hunters had a zoomorphic face ${ }^{37}$. Irakli Surguladze ${ }^{38}$ thought that hunting with its semantic defines the type of whole mythical episode, its religious-cosmogonic and social aspects; such is a hunting motive in Georgian mythology $y^{39}$. Individual images and compositions of animals that originated in archaic times and are explained on the grounds of cosmogonic and religious beliefs are widespread in traditional art. Such motives are found on decoration of objects of different purposes ${ }^{40}$. For example, bronze belt from the Samtavro Samarovani, approx. BC. Year The $12-9^{41}$ even such an important stage in the history of Georgia as entering of Christian religion was associated with hunting of King Miriani in IVth Century ${ }^{42}$.

As it is knownhunting of St. Eustace symbolically conveyed the conversion "from darkness to light", to Christianity, theophany (divine manifestation), the idea of soul salvation and, at the same time, was the materialization of the theological idea expressing the glory of Christ.

According to Khidasheli's conclusion, in medieval Georgian art, in the ideas expressed in "Vision of St. Eustatius" crucial significance for exempt-

35 Ibidem, pp. 94-95.

36 E. Virsaladze, Georgian Hunting Epos (Cycle of Perished Hunter), Metsniereba, Tb., 1964, p. 5.

37 Ibidem, p. 5.

38 I. Surguladze, Mythos, Cult, Ritual in Georgia, Tb. 2003;

39 Ibidem, p. 48.

40 Ibidem.

41 Ibidem, p. 114; I. Surguladze, symbolics of Georgian folk ornaments, Science, Tb. 1986, p. 114.

42 The life of Kartli (according to all the basic manuscripts written by S. Kaukhchishvili), t. I, Tb. 1955, pp. 111-118. 
ing from the idolarity and for becoming Christians has the vision occuring at the time of the hunting. This popularity of hunting motifs of St. Eustestus's Hunting on the deer at least partially, may have been caused by the fact that in the consciousness of the Georgian people hunting on deer and deer was especially meaningful. This fact was fully reflected in the ancient art of Georgia as well as Georgian folk culture ${ }^{43}$.

According to Mariam Didebulidze ${ }^{44}$, hunting was considered as the best condition for contact with divine and heaven forces in Georgian pagan mythological legends and folklore. Numerous manifestations of icons as well as discovery of holy relics and so on happened precisely during the hunting For example, Marika Didebulidze connects the idea of turning st. Eustateus into to King Mirian's hunting ${ }^{45}$. The "Turn to Kartli"46 gives us the story of a miracle, which happened during the hunting of Georgia's idol worshiper King, which lead his turning into Christianity. It is true that the deer is not mentioned in the text, but the similarity in the context is great - turning into true religion and the salvation of the soul ${ }^{47}$. According to "Turn to Kartli": "And it was the same day, in the summer of July twentieth, Saturday, the king went hunting in the oak in the private. When the sun went to darkness in the middle of the afternoon-meal, the sun went dark above the mountain was drowned in the night when the darkness was darkened and darkened and occupied the area and the places... God of Nino Show me in this dark, and show me my name and my place and I will admit your name and stand the cross. You are God of Gods and Lord of lords over all, as Nino says... As you save me from the grief and lighten the darkness of mine ${ }^{48}$.

The act of hunting is the best condition for overcoming the boundary between the earthly and heavenly, for transition into another dimension. In addition, in the samples of pagan art, a sacral meaning is attributed exactly to the act of pursuing the game, not to the game-eating, At the time of the persecution of the victim, animal takes the hunter to the secret place

\footnotetext{
43 M. Khidasheli, Ritual and symbol in archaic culture, Tb. 2005, pp. 248.

44 M. Didebulidze, op.cit., p. 204.

45 M. Didebulidze, op.cit., p. 203-204;

46 Mokcevai Kartlisai (Conversion of Georgia), Monuments of Old Georgian Hagiographic Literature, I (V-X centuries), Tbilisi 1963, pp. 81-163 (in Georgian).

47 M. Didebulidze, op.cit. pp. 204-205.

48 Mokcevai Kartlisai, op.cit., pp. 81-163.
} 
where he discovers treasure - e.g. Myth about Pharnavaz. In some cases, deer can be seen as a zoomorphic form of the Hunting God ${ }^{49}$.

According to Elene Virsaladze ${ }^{50}$, In Early Christian times Georgian church fought against the influence of pagan religion V-VII ${ }^{\text {th }}$ century ${ }^{51}$. Heads of Georgian Church used clever method: Christian art adopted the nature of Georgian people, its habits and customs and took and Christianized much from the pre-Christian epoch, including themes of hunting. It related episodes lives and miracles of saints to hunting themes and disseminate this model into the population.

\section{The Vision of Saint Eustace in Medieval Georgian Art}

Hunting scenes in Georgia are observed in the sculpture of VI century and develops unequally. It is necessary to mention the relief of the stone column of John the Baptizer (VI-VII cc.) (Fig.1), decorations of the west façade of Atenis Sioni (VII c.) (Fig. 2), the frieze of the east façade of Martvili Sioni (VII c.) (Fig. 3), Tsebelda iconostasis plate (VII-VIII cc.) (Fig. 4), the relief of the window of Tabatskuri (X c.), the hunting scene on the top of the window of Oshki (X c.), the relief of Tkoba-Ierdi in Ingusheti (X c.), hunting compositions of High Middle Ages of Ertatsminda (XIII c.), reliefs of Late Middle Ages of Sadgeri St. Giorgi Church (XV c.), Nicozi Ascension Cathedral (XVI c.?), Xeoti bell tower (XV-XIV cc.).

Fig. 1. relief of the stone column of John Fig. 2. Atenis Sioni (VII c.) the Baptizer (VI-VII cc.), Georgian National Museum
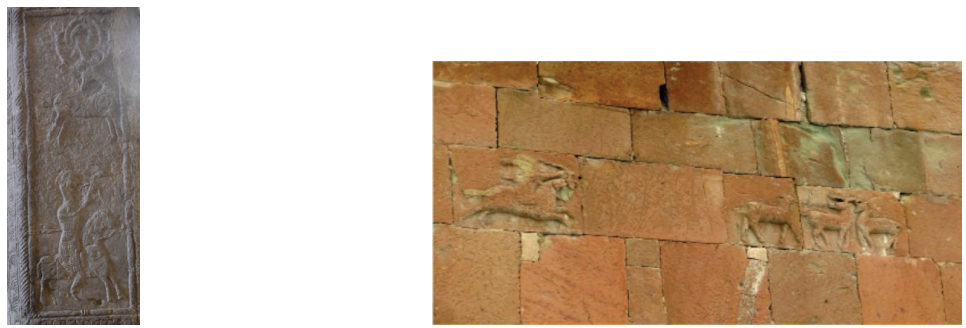

49 M. Didebulidze, op.cit., p. 204.

50 E. Virsaladze, Georgian Hunting Epos (Cycle of Perished Hunter), Metsniereba, Tb., 1964, p. 126-127.

51 Ibidem, pp. 126-127. 
Fig. 3. Martvili Sioni (VII c.)

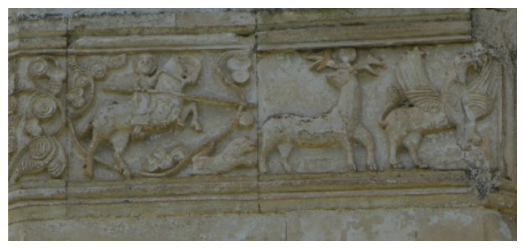

Fig. 4. Tsebelda iconostasis plate (VII-VIII cc.), Georgian National Museum

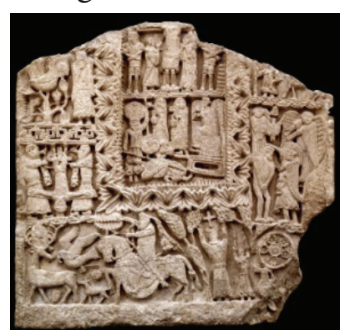

In XI-XVI centuries, above noted themes enjoy particular popularity in wall painting in Georgia. According to Tania Velmans ${ }^{52}$, images of the vision of St. Eustace enters the program of monumental painting of Georgia in XI century and continues existing on facades by old iconographic tradition till XV-XVII centuries ${ }^{53}$ (painting of Iphrali Church façade, on the verge of XI-XII cc., scenes of Xozita Mariam, Nuzal and Zenoban of XIII century, paintings of facades of the churches of Sapara and KaisheTaringzell (XIV c.), of Laghami and Lashtkhveri (XV c.), paintings of Late Middle Ages of Koreti, Ilemi and Ertatsminda).

The scenes of Eustace's vision are also found in miniature decoration of Georgian books of XVII-XVIII centuries (for example, Eustace and a deer in a scroll of XVIII century H-2076, kept in National Centre of Manuscripts, and Eustace on the horse, in the collection A-1454 (1746).

As it is known, hunting of St. Eustace symbolically conveyed the conversion "from darkness to light", to Christianity, theophany (divine manifestation), the idea of soul salvation and, at the same time, was the materialization of the theological idea expressing the glory of Christ.

Themes of hunting have roots in prehistoric epoch. The ancient tradition of the hunting institute in Georgia is confirmed by numerous historical data, ethnographic material, objects connecting to hunting (for example, weapons), which have survived since the Eneolithic. Archaeological sites of the Eneolithic, Bronze and Iron Ages on the territory of present day Georgia and in its vicinity comprise the materials that reflect hunting

\footnotetext{
52 Velmans T., op.cit., pp. 19-49.

53 Ibidem, p. 31.
} 
in abundance (weapons, animal monuments, etc.). Hunting motives are characteristic for so called oldest samples of Caucasian art, and images of wild animals are its main topic; even such an important stage in the history of Georgian nation as entering of Christian religion was associated with hunting.

According to Mariam Didebulidze ${ }^{54}$, hunting was considered as the best condition for contact with divine and heaven forces in Georgian pagan mythological legends and folklore. Numerous manifestations of icons as well as discovery of sacral treasure and so on happened precisely during the hunting. The act of hunting is the best condition for overcoming the boundary between the earthly and heavenly, for transition into another dimension. In addition, in the samples of pagan art, a sacral meaning is attributed exactly to the act of pursuing and not the game-eating ${ }^{55}$.

According to Elene Virsaladze ${ }^{56}$, Georgian church fought against the influence of pagan religion. Heads of Georgian church used clever method: Christian art adopted the nature of Georgian people, its habits and customs and took and Christianized much from the pre-Christian epoch, including themes of hunting. It related plots of lives and miracles of saints to this theme and brought it to the people in this form.

We found hunting compositions in Georgian relief sculpture on the facades of cathedrals, stone-crosses and in the decor of iconostasis. Georgian hunting compositions were developed by synthesizing the local, pre-Christian Georgian tradition on the basis of iconographic schemes worked out in Christian world: Horseman-hunter with a drawn bow and arrow pursues a deer or herd of deer, between antlers of which is depicted the cross or the Savior's face placed in medallion. In compositions (for example, Ateni Sioni, Martvili Sioni, Tsebelda iconostasis), horizontal direction is mainly emphasized, in some cases (for example, Stella of John the Baptizer) - vertical. At the early stage, Georgian reliefs experienced, on the one hand, an influence of the Hellenistic-Antique art, and, on the other hand, the art of Sassanid Iran. At the same time they developed individu-

54 Didebulidze M., op.cit., p. 204.

55 Ibidem, p. 204.

56 Virsaladze E., Georgian Hunting Epos (Cycle of Perished Hunter), Metsniereba, Tb., 1964, p. 5. 
ally. Master's particular approach, which was inspired by pre-Christian mythology, cult, art, and was relied on local beliefs, is seen in every composition; the character and peculiarities of each composition were created by accenting different details that, on its part, creates an individual character of medieval Georgian art. Pagan signs are especially represented on early monuments, for example, the deer depicted on the Stella of John the Baptizer reminds us deer depicted on the openwork buckles of the preChristian period, and the medallion with rosette depicted on its body is associated by Machabeli with the astral signs ${ }^{57}$. According to her, it has a sacral meaning.

Georgian hunting scenes, where the hunting of St. Eustace is found, unite two symbolic moments of his life: hunting and "theophany", i.e. vision of the Savior. The main feature is the monumental head of the Savior depicted between antlers of deer in relief sculpture (Stella of John the Baptizer, Martvili, Tsebelda...). Mostly the Savior is depicted in wall painting as well (Saphara), but in book miniature there is a cross between deer antlers (H-2076, the scroll of the XVII century, and A-1454, the collection of 1746).

Compositional solution has experienced development during centuries. An unmounted hunter-archer is depicted in the hunting scenes of X century (Oshki, Tkoba-Erdi), XI century (Bagrati) and XV century (Sadgeri). Proceeding from it, it should contain an idea different from the hunting scenes of an earlier period. In our opinion, this unmounted hunter might be an image of the Zodiac Archer. Jobadze's considerations confirm supposition about the Zodiac Archer. The scientist thinks that reliefs on the south façade of Oshki are associated with the astrological universe..$^{58}$

It should also be mentioned, that depiction of the Zodiacal signs on the cathedrals and attachment of religious content to them was common in the West European Christian world of this period (for example, cathedrals of Auvergne (XI c.) and Vézelay (1120-1150) in France, St. Nicolas small church in Barfrestone (circa 1100), in England.

57 Machabeli K., Georgian Stone Crosses, Tb., 1988, p. 291.

58 Djobadze V., Early Medieval Georgian Monasteries in Historic Tao, Klarjeti, and Shavsheti, Universali, Tb., 2007, p. 142-143. 


\section{The Vision of Saint Eustace in Medieval French Art}

In medieval France the lives of Saints are spoken about in poems, legends, popular dramas, those concerned try to preserve the illustrations of holidays and important events of Saints' lives by means of all fields of the visual art or oral literature. By it they glorify and honour them for being mediators before the God. There is some kind of cult of Saints in France ${ }^{59}$ (even today, the streets, subways... are named after them, for example, Saint Placida, Saint Michel and so on). Their respect was greater than antique idolatry. The saints interfere in human life as gods of pagan Rome ${ }^{60}$.

According to literary sources, the cult of St. Eustace appeared in France in XII century ${ }^{61}$. The plot of his life became the favourite topic of medieval France. His life "drama" was attractive and acceptable for the art of this epoch that is confirmed by the multiplicity of his images (stained-glass windows of Auxerre, Leman, Tours etc) ${ }^{62}$.

St. Eustace's images occupy an important place in the cathedrals of medieval France. If these compositions in Georgia are generally placed on the edges of doors and windows, facades, iconostasis and Stella, in France, for this purpose, they resort to decors of stained glass windows, refectory, entrance tympanum and portals, and some separate symbols are sometimes found on the upper part of facades, on pediments (for example, St. Eustace Cathedral in Paris, XIII c.).

Judging by the number of samples found, hunting themes became more relevant in France than in Georgia. Of French monuments, St. Eustace relief composition on the capital of narthex on the Basilica of St. Maria Magdalena in Vézelay (1120-1150) (Fig.5) is worth of noting, the stained glass of the north nave of Chartres (XIII century, Fig.6.) Cathedrale of Saint-Gatien of Tours (XIII c.) (Fig.7), as well as the relief of the refectory of Saint Dennis Basilica (XIII c.) (Fig. 8) . Paris Cathedral is built after St. Eustace (XIII c.), and reflect his life. In the Late Middle Ages, in France the iconographic scheme

59 Male É., l'Art religieux du XIIIe siècle en France, Étude sur l'iconographie du moyen âge et sur ses sources d'inspiration, Paris 1898, p. 347.

60 Ibidem, p. 341.

61 Denis M., op.cit. p. 39.

62 Male É., op.cit. p. 352. 
of Placida's vision gives way to the iconographic scheme of Hubert's vision, but continues its existence in book miniature. Samples of numerous miniatures are kept in the Manuscript Department of French National Library, for example "Golden Legend" of Jacobus De Voragine (XV century), Encyclopedia of Vincent of Beauvais (XIV century) and so on. In miniatures, Placida is mainly depicted as praying, unmounted and knelt in front of a deer, and between the antlers the monumental head of the Savior is depicted. It is also represented in French and Belgian manuscripts of XIV-XV centuries kept in the Manuscript Department of French National Library, for example, The Vision of St. Eustace, Life of Saints, French manuscript (183, 231v) (XIV c). Though, it should be noted, that the themes of St. Eustace are not forgotten with the strengthening of the cult of St. Hubert. Apart from France, we find plots of his visions in Italy, Germany and England, both in Renaissance painting (for example, The Vision of St. Eustace by Italian painter Pisanello 1438-1442, London National Gallery, The Vision of St. Eustace by German Albrecht Durer (1501), Saint Louis Art Museum (USA), The Vision of St. Eustace by unknown painter (1500, Germany) and in wall painting (wall painting of Canterbury Cathedral in England (1480)).

Fig. 5. Narthex capital of St. Maria Magdalena Basilica in Vézelay (1120-1150)

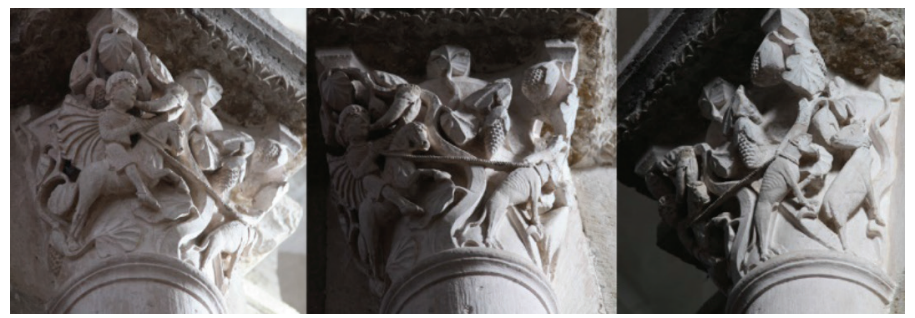

Fig.6. Stained glass on the north nave of Chartres (XIII century)

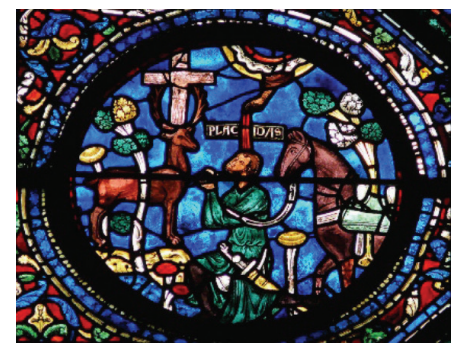


Fig.7. Life of St. Eustace (XIII century) Saint-Gatien of Tours

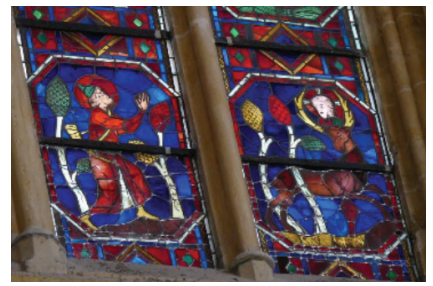

Fig. 8. The relief of the refectory of Saint Dennis Basilica (XIII c.)

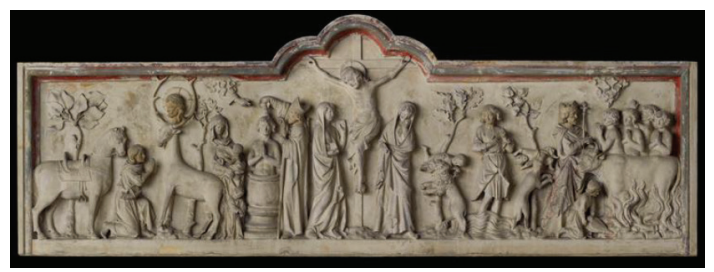

The earliest composition of hunting scenes in French art is "Hunting of St. Eustace" of the XII century, on the relief of the narthex capital of St. Maria Magdalena Basilica in Vézelay (1120-1150). Its characteristic feature is that, like in Georgian examples, during hunting Placida is depicted as a horseman and not as praying, but unlike in Georgian comparanda, he hunts with a trumpet in his hand (it is characteristic for French scenes). There is no necessary iconographic sign in the composition - the image of the cross or the Savior between deer antlers. Only one moment is represented here, namely, hunting without theophany. A figure of a dog also depends on the horseman. He leads the dog with a drawn rope, stops it before a pursued animal at the moment of attack. Figures of the horse, dog and animal are symmetrical. Free spaces between figures are filled with grapes and shoots of vine. The contours of the soft, flowing lines of floral ornament impart dynamism to the composition.

In European compositions with St. Eustace the story is mainly told, for example, there are some compositions on the stained glass on the north nave of Chartres (XIII century, Fig. I): hunting in the centre, where two horsemen pursuing deer are depicted, the central figure, like in Vézelay, is represented with a trumpet in his hand; dog figures are also included in the composition. Figures of unmounted man and group of dogs are placed in round medalions around the central composition on the stained glass. The 
scene of the vision is given above the hunting, on the left side, and on the right there is a scene of saint's baptism. In the centre, in a medallion, Eustace is kneeling on one knee in the pose of supplication in front of a deer, and the deer is with a monumental cross between his antlers. He is pulling a bridle of a horse. The blessing hand is descending from the sky above his head that is rarely observed in French art, and, as for Georgian art, it is attested nowhere. This detail, namely, the blessing hand, causes an association with the figure of an angel descending from the sky in the iconographic scheme of Hubert, worked out in later period. Contrasts, created by the colours of stained glass, increase the impression of theophany.

The stained glass of the Cathedral of Saint-Gatien of Tours of the same period also reflects the life of St. Eustace (XIII century). Several compositions are devoted to the episodes of the saint's life here as well, namely: hunting, vision, torture in a "brazen bull"... Unlike Chartres, three figures are depicted here in the hunting scene: a horseman with a trumpet in his hand is going towards a deer. A dog attacks the deer. Stained glass windows are solved in dark colours, figures of the dog, deer antlers and the horse are white. Eustace's garment, a dark green dress with a red cloak, creates a contrast. St. Eustace is represented with a triangle red cap in the hunting scene, that indicates at his being a lay man.

If in the hunting scene the lay man "pursuer" is Placida (in the moment of pursuing deer), in the composition of the vision the saint is represented as "hunted by a deer", "a follower of the Savior". The unmounted figure with slightly bent legs and hands, raised obediently, goes to the deer, with trumpet hanging on his side and a triangle cap of a green colour on his head. The red halo indicates his holiness. The head of the deer is turned towards Placida, and unlike Chartres, there is the Savior with white face (denoting radiance) and with red halo between its antlers instead of the cross.

Of the monuments of the medieval French sculpture, we can name the relief of the refectory of Saint Dennis Basilica (XIII c.) as an example of the vision of "St. Eustace Placida". Here again, like in Chartres, the story is told and key moments of Eustace's history are depicted - his conversion to Christianity, baptism, trials (loss of children) and martyrdom (the idea of soul salvation). Composition of theophany, divine manifestation, on its side, reflects the glory of the Lord. 
Horizontal stone plate of refectory is framed with rectangular band, with cut in its middle. Framing is elevated in the centre in the form of three vaults, by which it corresponds to the composition of the crucifixion, depicted under it. The composition, resolved horizontally, tells about important episodes of the life of St. Eustace: vision - the beginning of spiritual life of Eustace, baptism together with family, telling of story begins with the hunting scene, with "theophany" - the holy beginning, crossing of a river and loss of children, the story ends with the torture of his family in a "brazen bull". Similar to the stained glass of Saint-Gatien of Tours, praying Placida knelt before a deer (with the image of the Savior between its antlers) is represented here. Unlike compositions of Vézelay, Chartres and Tours, the saint is depicted here without a trumpet.

In contrast to the Georgian examples, the stage following theophany recognition of God by a horseman converted to Christianity by the vision of Christ, and not the moments of pursuing, confrontation and attack, is emphasized in hunting. It resembles the face of the deer of Georgian John the Baptizer according to its artistic processing: long neck, crowned with branched antlers made by soft semi-circled lines, that repeat the silhouette of the halo of the Savior, depicted in it. The way of performing figures is distinguished by great skill, working out of details imparts expressiveness to the relief. In this case, supposedly, the theme of soul salvation is thought out together with the idea of patience and overcoming evil by faith.

\section{The Vision of Saint Hubert in French Art}

As we have mentioned, the hunting scene of St. Hubert acquires greater popularity in relief compositions and painting in France in XV-XVI centuries. It should be noted, that the plot of the vision and conversion to Christianity of saint martyr Eustace formed the basis for the iconographic scheme of the vision of St. Hubert, spread in the Catholic world. It is explained by the fact that spiritual transformation of St. Hubert, like that of Placida, is connected to the vision happened during hunting.

Small chapels named after St. Hubert are built in great number in XV-XVI centuries (Amboise, Chauvirey Le Châtel, Ardennes and others). An interesting sample of the iconographic motive of St. Hubert is given on the 
relief of the portal of St. Hubert Chapel of Amboise (XV c.) (Fig.9), on the bas-reliefs of the refectory of St. Hubert Chapel of Chauvirey Le Châtel (XV c.) (Fig.10) and St. Hubert Chapel of Rahing (XV c.) (Fig.11), on the bas-relief of the refectory of Talan Cathedral of Our Lady (XVI c.) (Fig.12), on the bas-relief of Saint Martin Chapel of Tourelles (XVI c.) (Fig.13), on the bas-relief of the tympanum of Ardennes (XVI c.) (Fig.14).

The fact is worth of noting, that St. Hubert chapel is also in England, Eadsworth. It is built in 1030, but initially it was named after Peter and Paul, and got Hubert's name in the 19th century, after the wall painting left on the north wall of the chapel had been studied, where St. Hubert is depicted together with John the Baptizer (the painting is dated 1330) ${ }^{63}$. Similar to the vision of Eustace, we find Hubert's themes in Renaissance painting, in the works of Dutch artists of the XV-XVI centuries, for example: the reburial of St. Hubert in St. Peter's Cathedral in Liege, Roger van der Weyden, 1437, the vision of St. Hubert, Pieter Bruegel and Rubens, 1617, Madrid, Prado Museum. The vision St. Hubert is reproduced in stained glass windows of St. Patrick's Basilica (Ottawa, Canada), 1898 (it is performed according to the design of German company Franz Meier), and in stained glass windows of St. Catherine's Cathedral of Herringswell, England, 1902.

We have an interesting example of relief sculpture of St. Hubert on the grave of Da Vinchi, on the portal of St. Hubert Chapel of Gothic style in Amboise (XV). The tasteful authors of this masterpiece are known, these are the three masters - Pierre Minar, Kasin Dutrecht and Corneille de Neuf $f^{64}$. Composition unfolds horizontally, on the right side Hubert is represented, kneeling on one knee, pulling a bridle of a horse by the left hand, and taking off his hat before a deer by the right hand, as if expressing respect by this knightly gesture. A figure of an angel obliquely flying above his head, as if extends the crown to Hubert's head. Here, too, Hubert and the deer are depicted against each other. From a group of dogs one is kneeling before the deer, and two of them are ready to attack. The crucified Savior is depicted between the antlers of the deer. It seems as if the deer stands on a slope. The rocky cliff separates the hunting scene from the figures depicted

\footnotetext{
63 http://www.hampshire-history.com/series/south-east-hampshire-churches/.

64 Babelon J.P., le Château d'Amboise, 2004, pp.-60.
} 
on the left area - St. Christopher with the Savior on his shoulders and Saint Anthony the Great in his cell with a pig, in the corner ${ }^{65}$. (A stick and a beard are attributes of St. Christopher as of a hermit. He is a symbol of strength in Christian art. Christopher resembled Heracles - the Greek hero, who disappeared from the mythology in the Middle Ages and revived in a person of Christopher $)^{66}$. St. Anthony is so bent as if he watches events taking place in the composition. The free areas are full of trees of different sizes, leafbearing trees located by plans create the imitation of a forest, and the nature is realistically reproduced. Heads of various animals sticking out of dark, in-depth places give rise to a sense of danger, presaging the earthly evil. Depiction of St. Anthony the Great and his association with Hubert might be of symbolic-allegoric character. He is considered the founder of monastic life in the Christian world. His inclusion into composition gives us an indication and, possibly, implies Hubert's spiritual transformation after theophany, beginning of his monastic life.

The sculpture worked out the well known scene creatively. Elastic, soft contour of figures sharply raised from the background create expressive dynamics of the figures. The centre of the horizontal composition is the deer standing at the rock cliff. The deer is underlined both iconographically and semantically. It is a main symbolic character by means of which the Savior manifests and the connection between man and God is established. The other figures are placed to the left and the right of it. Every element of composition is worked out in detail. Hubert's draped garment, curly hair, similar to a wig, falling to his shoulders are clearly visible. The figure of the angel placed obliquely, the outline of wings and its pose creates an impression of light flight. The figures of Christopher and Hubert are directed by their bodies towards a spectator, and by their faces in profile to the crucifixion. Placement of the figures and variability of the poses of their bodies create symmetry. Details are proportionally and commensurately directed to the centre. Lively, dynamic poses make composition expressive. Impressions of chaos, calmness, anticipated danger and glory take turns of each other.

We have Hubert's scenes of Chauvirey Le Châtel (XVI) and Saint Martin of Tourelles (XVI c.) in shortened iconographic version. Rahing's bas-relief

\footnotetext{
65 Babelon J.P., op.cit. p. 60.

66 Male É., op.cit., p. 354.
} 
(XVI c.) differs with a few details. Extensive iconographic version of $\mathrm{Hu}-$ bert's hunting is given on the bas-relief of Talan refectory (XVI). Different iconographic scheme is on the bas-relief of the tympanum of Ardennes.

Everywhere in above mentioned compositions, Hubert is depicted unmounted, praying in front of a deer (like French Eustace). In contrast to them, there is a horseman saint on the tympanum of Ardennes. In every scene the crucified Savior is between deer antlers, with the exception of the relief of Ardennes, where there is a cross instead of crucifixion. St. Hubert, like St. Eustace, is mostly represented with a trumpet and a sword hanging on his side (excluding Ardennes and Rahing). There is a lance instead of a sword in the Rahing example. The tree depicted in the centre of Talan and Ardennes reliefs divides the composition into two parts. It separates St. Hubert and the deer from a retinue on the Talan relief, and separates St. Hubert and the deer from each other on the Ardennes one. This division as if emphasizes the difference between the earthly and heavenly universes, which are connected by the tree of life. The significance of the "tree of life" is underlined. Half-figures of angels are depicted on the reliefs of Chauvirey Le Châtel, Rahing, Talan, Tourelles. But, like in Amboise, a whole figure of an angel with omophorion in hand is given on the relief of Ardennne. Depiction of half-figures in the composition in Chauvirey Le Châtel seems to be dictated by the form of the stone plate and a master used it because of tectonics.

Fig. 10. Chauvirey Le Châtel (XV c.)

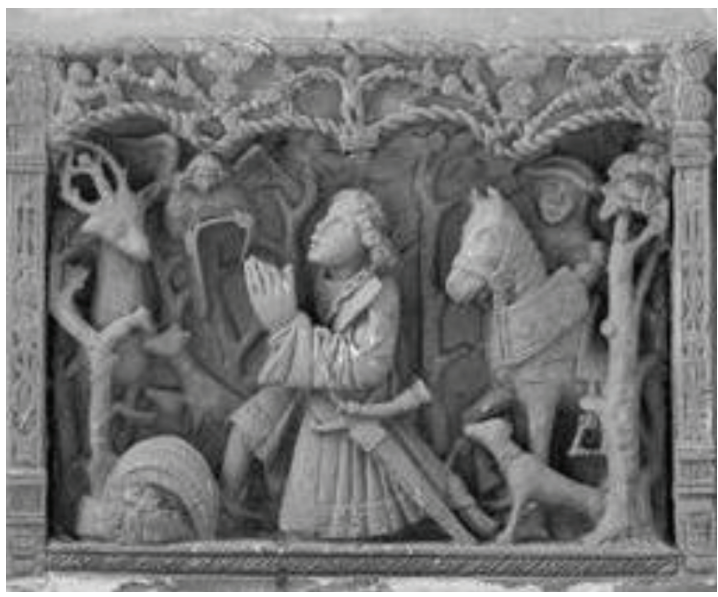


Fig. 11. St. Hubert Chapel of Rahing (XV c.)

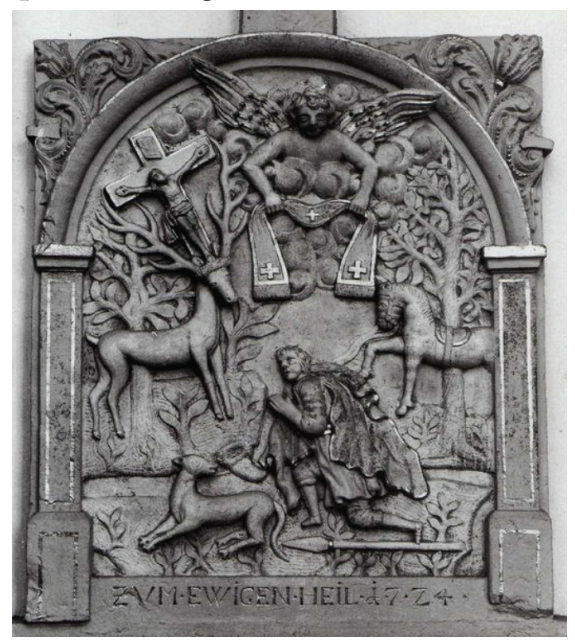

Fig. 12. The bas-relief of the refectory of Talan Cathedral of Our Lady (XVI c.)

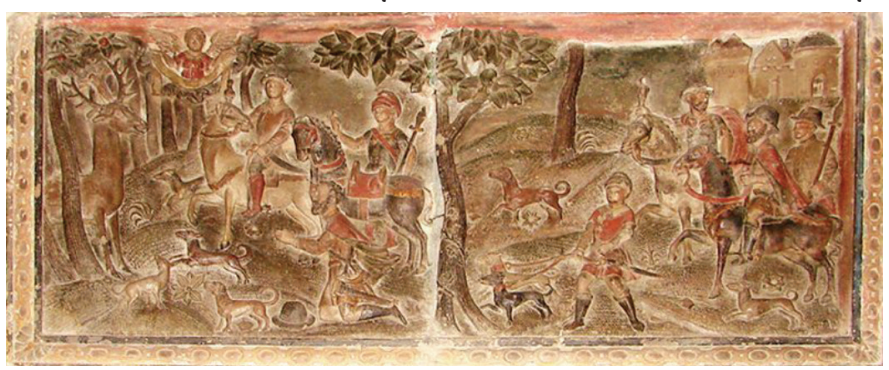

Fig. 13. The bas-relief of Saint Martin Chapel of Tourelles (XVI c)

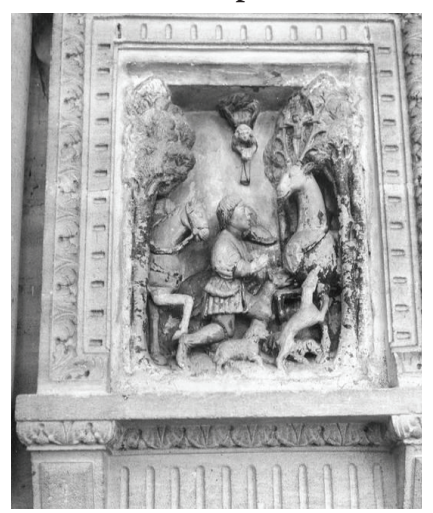


Fig. 14. The bas-relief of Saint Martin Chapel of Tourelles (XVI c)

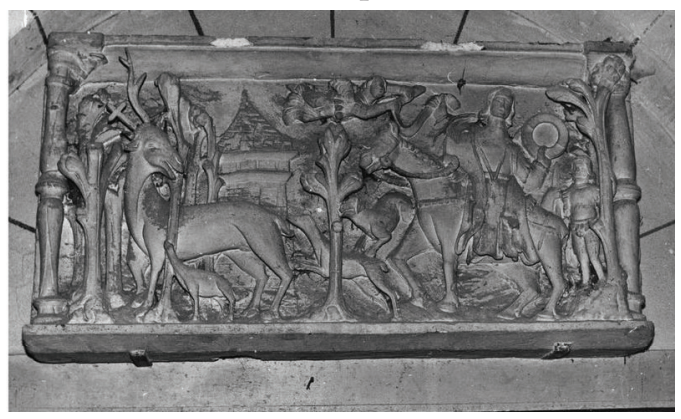

Stylistically, it is characterized by conventionality, and it accentuates semantics by means of expansion of scales of separate details. For example, it accentuates the moment of supplication and praying by enlarged hands of Hubert. On the relief of Tourelles, the angel holds a folded omophorion, but in others it is unfolded, in the moment of blessing. On the relief of Ardennes, one end of an omophorion is held by the angel, the second by the saint. As in Amboise, the saint is represented with took off hat on the relief of Ardennes, though the hat is stretched out to the side and not towards the deer. The deer as if observes the moment of blessing of the saint by the angel. In contrast to other compositions, the deer is depicted at the moment of pursuit, its head is turned towards Hubert, but body is not. The dogs attack the deer. Architectural details make the background behind it. And Hubert opposes the intense moment developed on the left side with a calm and balanced pose. Half-naked figure of a man is represented behind Hubert. Supposedly, it is an allegorical image of Adam, as a recollection of man's falling, sins and earthly life.

If we group them typologically, If the separate scenes are for hunting and the revelation in St Evstat's vision, the Hubert's iconographic scheme combines hunting and vision in one composition. In the Ichnographic scheme of St. Eustace's mostly Savior is depicted between the deer horns. (e.g, the relief of the refectory of Saint Dennis Basilica (XIII c.) life of St. Eustace (XIII century) Saint-Gatien of Tours), the exceptional is stained glass on the north nave of Chartres (XIII century). In Hubert's iconographic scheme the must is the crucifixion, which is essentially derived from his biography - his vision is related to Red Friday, with the Day of the Sav- 
ior's Torture, accordingly this important element of the composition in its iconographic scheme has changed. Two main characters of the composition of Eustatius are the Saint and a Deer with Savior's image depicted between the horns, which indicates to their dialogue. In the case of Hubert, the symbolic scheme involves an angel in the hands of an Omophorion in his hands, this element represents the Hubert's spiritual breakthrough, symbolizing his future-bishop's blessing. Garment - St. Eustat is represented by a long cape, in some places on the head of three-dimensional hat (life of St. Eustace (XIII century) Saint-Gatien of Tours), which reminds us that the Byzantine period hunter kills Female Lion, Mosaic of Mosse's Church, V-VI cc. Jordan, in some places without the hat (stained glass on the north nave of Chartres (XIII century), the relief of the refinery of Saint Dennis Basilica (XIII c.)). Saint Hubert is different from Eustace, wearing a short, drummed cloth above the trousers. St. Hubert Chapel of Amboise (XV c.), Chauvirey Le Châtel (XV c.), The bas-relief of Saint Martin Chapel of Tourelles (XVI c)). His dress, garment, and hair reminds us Jordan, Madaba of V-VI centuries ${ }^{67}$, Nebo and Aman Byzantine mosaics from shepherds-bear and lion-hunting compositions (Mosaic of Mosse's Church, 530 year. Nebo Mountain, Jordan. mosaic of the floor of the deacon Toma, Madaba, The Mother of God's Church, Hippolytus Hall's floor mosaic, VII Jordan., Moses Memorial , Hunting on the bear, 530 years ${ }^{68}$.

Half-figures of angels are depicted on the reliefs of Chauvirey Le Châtel, Rahing, Talan, Tourelles. But, like in Amboise, a whole figure of an angel with pallium in hand is given on the relief of Ardennne. Depiction of halffigures in the composition in Chauvirey Le Châtel seems to be dictated by the form of the stone plate and a master used it because of tectonics. Stylistically, it is characterized by conventionality, and it accentuates semantics by means of expansion of scales of separate details. For example, it accentuates the moment of supplication and praying by enlarged hands of Hubert. On the relief of Tourelles, the angel holds a folded pallium, but in others it is unfolded, in the moment of blessing. On the relief of Ardennes, one end of an omophorion is held by the angel, the second by the saint.

67 M. Nassar, The art of decorative mosaics (Hunting scenes) from Madaba Area during Byzantine period ( $5^{\text {th }}-6^{\text {th }}$ c. Ad), Mediterranean Archeology and Archaeometry, Vol 13, N-1, Greece 2013, pp. 68-76.

68 Ibidem, pp. 68-76. 
As in Amboise, the saint is represented with a took off hat on the relief of Ardennes, though the hat is stretched out to the side and not towards the deer. The deer as if observes the moment of blessing of the saint by the angel. In contrast to other compositions, the deer is depicted at the moment of pursuit, its head is turned towards Hubert, but body is not. The dogs attack the deer. Architectural details make the background behind it. And Hubert opposes the intense moment developed on the left side with a calm and balanced pose. Half-naked figure of a man is represented behind Hubert. Supposedly, Probably it is accompanied by tree of life it is an allegorical image of Adam, as a recollection of man's falling, sins and earthly life (mosaic of Capella Palatina (detail) XII, Montreal, Palermo XII century $)^{69}$. It is noteworthy st. Augustine's paradox as far as the free will of humanity is concerned and his predestination to death. Adam had been created with freedom; that freedom differentiates from the one that the fallen man has. The latter always tends to evil, while the true freedom is the submission to God's will ${ }^{70}$.

Thus, St. Eustace Placida's hunting compositions were singled out in Christian art of medieval Georgia, and scenes of the hunting and vision of St. Eustace in parallel with those of St. Hubert in the West European art. Given that Georgia had close ties as with Byzantine as Syria and Sasannian $\operatorname{Iran}^{71}$, Synthesis of Ichonographic elements is reflected in Georgian art, which is well reflected in St. Eustace's hunting scenes. For example Stainless steel tile Eustaasti hunts wild accompanied by a dog. According to Saltikov ${ }^{72}$, that is rare for Byzzantian art but is close to scenes of Syrie and Sassanian Iran.

St. Eustace is the Roman saint of the II century, of the epoch when Christian faith is still spreading in the struggle against paganism. And St. Hubert is the Franck knight of the VII-VIII centuries. Eastern Christian art accepted the hunting scene of St. Eustace earlier than the West European one.

69 V. Vasiliki Mavroska Fachbereich Sprach, Adam and Eve In The Western and Byzantine Art of The Middle, Ages, Frankfurt 2009.

70 Ibidem p.-33.

71 A.A. Saltykov, La vision de saint Eustache sur la stele de Tsebelda, Cahiers Archeologiques, Picard, 1985, p.-10.

72 Ibidem, p. 11. 
According to Tania Welmans ${ }^{73}$, the basis of St. Eustace's hunting scene is the hunting of the King of Egypt and Assyria in the Old East ${ }^{74}$. According to Fadman ${ }^{75}$, hunting was topical to 3,000 years ago, especially in Mesopotamia ${ }^{76}$, with many examples of King Asburnifal hunt cycles (present Iraq) presented at the Ninevee Palace sculpture ${ }^{77}$. According to Mahmud Nasari, the composition of the king of the northern palace of Nineveh King Asubanifal (Room C, Panel 25-28) (Fig. 19, 20, 21). Date back to BC Year 645-635 years (protected by British Museum, London) ${ }^{78}$.

\section{Conclusion}

Based on materials, it is seen that themes related to Eustace were more popular in France in comparison with Georgia. Cathedrals built in his name, stained glass windows, relief scenes, miniatures showing saint's life, and his variation in the form of "St. Hubert" speaks on obvious, strengthened cult.

On the grounds of the examples considered, it is possible to list the peculiarities of the iconographic scheme of the French hunting compositions of St. Eustace and St. Hubert: at one side there is the saint in front of the deer, mainly knelt, in the pose of supplication; exclusion is the relief of Vézelay capital, where Placida is represented as a horseman. In contrast to the Georgian examples, the scenes of the hunting and the vision of St. Eustace exist separately - on the one hand there is the moment of the hunting and pursuing the deer, on the other hand there is the scene of the vision of the Savior. In Georgian comparanda, the hunting and theophany are united. In the case of Eustace, like in the Georgian examples, we have mostly Savior's image between deer antlers, but in some places, a cross (Chartres),

73 T. Velmans, L'église de Zenobani et le thème de la Vision de Saint Eustache en Géorgie, Cahiers Archeologiques, Picard, 1985, p-38-39.

74. Ibidem, pp. 38-39.

75 M. Feldman Art and Imperialism in the Ancient Near East, History of Art and Near Eastern Studies, UCB, 2010, pp. 51-53.

76 Ibidem, p. 51.

77 P. Collins, Introduction and The Art of Ashurbanipal, Assyriian Palace Sculptures, The Trustees of The British Museum, 2008, pp. 8-27, 97-141.

78 M. Nassar, The art of decorative mosaics (Hunting scenes) from Madaba Area during Byzantine period $\left(5^{\text {th }}-6^{\text {th }}\right.$ c. Ad), Mediterranean Archeology and Archaeometry, Vol $13, \mathrm{~N}-1$, Greece 2013, pp. 69. 
and more rarely crucifixion (Encyclopedia of Vincent of Beauvais, XIV) are also attested. In Hubert's case, the Savior is always depicted as "crucified", rarely there is a cross (Ardennes). Sometimes a blessing hand is involved in the French vision of Placida, and in Hubert's case the necessary character is an angel with an omophorion in his hand, descending from heaven. Unlike the Georgian examples, French St. Placida and St. Hubert are often reproduced with a trumpet, in different interpretations: in some cases a trumpet is lifted up (in the scenes of hunting), in some cases it is hung with a sword on the side (in the moment of vision). It depends on the plot, which is reproduced by composition. There are some variations of the iconographic scene of the French vision of St. Eustace: unmounted Placida knelt in front of a deer (Chartres, the relief of Saint Dennis, wall painting of Church of St. Eustace in Paris), unmounted Placida, pursuing a deer (stained glass of Saint-Gatien of Tours). Hubert's scenes are enriched with biblical allegoric characters: Adam, Anthony the Great, Christopher... There are extensive and shortened versions of the hunting scenes in France, as well as in Georgia. The composition in the extensive version is enriched with a group of dogs, human figures and plant ornaments.

In French iconographic scheme, unlike Georgian iconographic scheme of St. Placida, where earthly and heavenly principles are sharply oppose each other, the struggle between Christianity and "Paganism", triumph of Christ, trials, finally martyrdom, patience and eternity obtained by it, are differently read. There are more elements of narrative, secular motives here, while symbolic indications prevail in Georgian examples. Given that the symbolic-allegorical faces of the new religions common for the early Christian art are occupying the place ${ }^{79}$. Religion is trying to adapt to local traditions and to establish this way in Georgia.

The popularity of scenes of St. Eustace's hunting in Georgia is explained by the fact that a formentioned plot is associated with the history of the conversion to Christianity of King Mirian as a result of the miracle that happened to him during the hunt. Perhaps, through the merger of these two events, a generalized image of divine manifestation and conversion to Christianity is represented ${ }^{80}$.

\footnotetext{
79 T. Dadiani, E. Kvachatadze, T. Khundadze, op.cit. pp. 16-17.

80 Ibidem, pp. 24-25.
} 
St. Hubert's popularity in France could be explained by an attempt to promote the national saint and historical figure. France tried to defend its interests as a state, to impose its models and retain originality. A Gothic French style linked especially to Paris cultural influence spread out as an international esthetics in the XIII ${ }^{\text {th }}-\mathrm{XIV}^{\text {th }}$ centuries. French Renaissance of the XV century followed the Italian Renaissance mutation process and acquired a national character through the synthesis of spiritual and secular motives linked to humanistic ideas. ${ }^{81}$ It is possible to suggest that those cultural changes conditioned the fact that ascetic life and martyrdom of St. Eustace of the early Middle Ages was replaced by a humanistic approach of conversion - the possibility of committing a lay man, Hubert, on the spiritual path.

Proceeding from it, the "revival" of the plot of the life of French saint in Christian art is not accidental. He was recognized and accepted by the Pope of Rome already in his life pope Sergius I (VII-VIII) ${ }^{82}$. Hubert was not a strong holy nor political saint in medieval France, at least all that differs according to the centuries and places: he was an aristocrat and a great figure of conversion in Merovingian times / he was an important saint in the Ardennes and a patron for hunters, which also makes a strong link with aristocracy, as only aristocrats could practice horse hunting, not common people... this was one of the most important distinctive social element;

As for the Georgian art, We meet the compositions of the St. Eustat's from the Early Christian period - VI-VIII cc. The popularity of the hunt in the early Christian times can be explained by the fact that In the Idea of turning into St. Eustat's religion Georgian art saw the miracle that occurred during the hunt of the Georgian King, which led to his turning into Christian faith. It is true that the deer is not mentioned in the text, but the contextual similarity is great - turning into true faith and the salvation of the soul ${ }^{83}$.

And when the cult of saints in Merovingian times, less in Carolingian times but again in Ottonian times, this cult was mostly based upon local

81 Ibidem, p. 418.

82 S. Baleau, Les sources de l'histoire de Liège au Moyen Age, Etude critique, T I, Bruxelles, 1903, pp. 40-45.

83 M. Didebulidze, op.cit. p. 204-205. 
saints: aristocrats for Merovingian times, more often monks in Carolingian times - read André Vauchez - and not any more Roman martyrs but the most famous linked to the New Testament, people chose as a patron of hunting and hunters a local saint people desperately needed relics for their church foundations, but above they needed local saints to protect them in their social and political local communities. His cult was actual even in those countries which were associated with the St. Hubert bishopry (Bishop of Liege and Maastricht), that is to say actual Belgium, England, Germany and the Netherlands.

From the stylistic point of view, the sculpture of the Middle Ages in France is symbolic. As for processing, it is characterized by rounded, elegant forms sharply raised from a background, in some places even the influence of Antique art is observed - soft contour, processing of garment; accentuating the processing of details, significant semantic load is emphasized. We could explain returning to the Antique art by the epoch of Renaissance, as it is the epoch different by its stylistic and artistic tasks.

It should be noted that despite thematic proximity, iconographic versions and their compositional solution differs from each other in French and Georgian examples. Ichonographic schemes of St. Eustat's vision are charachterized to be simple, as mentioned, these compositions combine two stories of Saint's Live - the hunting and the vision. The hunter rider in the composition is directed to the deer, the deer is the refugee - in the scheme it directs its head towards the hunter and the face of the Savior in the medallion is presented between the horns. These are two main characters of the Ichonographic scheme of Georgian St. Eustat (Johan the Baptist's Stella, the tile of Tsebeldi, Martvili Sion). The rest are already interpretations, we have a simple two-figured composition-Johanne Baptist's Stella, and a multi-figurative (Tsebelda, Martvili Sioni, Ateni Sioni) where the hunter hunts on the three-figured deer group on Aten, on Martvili Sioni's Frizzet with a dog and a composition contains a fantasy animal griffon. The free areas are decorated with plant element-clover length line. The hunter-rider sticks to the victim with the eagle and the dog.

Hunting compositions of medieval France are distinguished with the multiplicity of their iconographic schemes The hunter or the deer with the Savior's image between the horns ( the relief of the refectory of Saint 
Dennis Basilica (XIII c. stained glass on the north nave of Chartres (XIII century), St. Hubert Chapel of Amboise (XV c.)). French Christian art offers us special types of compositions French Compositions of st. Eustat have more story-telling. Iconographic schemes are also diverse. The life of the saint's life is divided into two stories, separately representing the hunt where the rider saint hunts by the sirens, officials, by dog or dogs on the group of deer. (Chartres), In some places, the original composition of Eustat's life episodes is only a moment of the vision (the relief of the refectory of Saint Dennis Basilica (XIII c.) without the hunt. In French compositions, Plaquida is represented in the form of a rider in the hunting scene and in the vision scene - on foot, kneeling with the Savior's image between the horns, which emphasizes the moment of the vision and the call of the Savior In Contrast with St. Eustat. In the same way as in Georgian combines in one composition the hunting and the vision the Ichonographich Scheme of St. Hubert's. Similaly with St. Eustat's composition, here is also reflected Saint-on horse, The Deer showing crucifixion between the horns. In the form of the rider is reflected on only on the relief of Arden Timphan. The charachteristic of the St. Hubert's scheme is - the image of the crucified Savior between the Deer's horns and an angel holding an omophore in her hands. St. Hubert's iconographic schemes are characterized by diverse and free solutions. Enriched with animal paintings, officials, ((the bas-relief of the refectory of Talan Cathedral of Our Lady (XVI c.)) And in Some places by Biblic characters (St. Hubert of Amboise). All these peculiarities create an individual character of each composition.

In comparison to the Georgian examples, there is a much freedom in solution of a plot, they follow the main scheme, but the interpretations are different, that should be caused by local traditions, worldviews, epoch, historical-cultural conditions. Although common ideas on theophany recognition of God, his glory and the idea of soul salvation - characteristic for Christian religious ideology were somehow reflected in sculptural décor. 


\section{Bibliography}

Abramishvili G., Deer symbolics on the relief of Ateni Sioni Tympan, Essays VI, Tb. 2000.

Abzianidze Z., Elashvili K., Illustrated Encyclopedia of Symbols, Vol. II, Bakmi, 2006.

Aladashvili N., The interrelation of medieval Georgian monumental and small sculptures, Fine and decorative-applied art, compilation of scientific works, Tssa, Tb. 1998.

Dadiani T., Kvachatadze E., Khundadze T., Medieval Georgian Sculpture, George Chubinashvili National Research Centre for Georgian Art History and Heritage Preservation, Tb., 2017.

Didebulidze M., "The Vision of St. Eustace” in Medieval Georgian Art, Literatura da Khelovneba, N2, 1990 (in Georgian).

Mamasakhlisi L., The Cult of a Deer in the Culture of Caucasian peoples, Caucasiological Papers N5, Institute of Caucasology, Tb., 2013 (in Georgian).

Machabeli K., Georgian Stone Crosses, Tb., 1988.

Machabeli K., Georgian Historical Costume (V-X centuries), Tbilisi, 2013 (in Georgian).

Mokcevai Kartlisai (Conversion of Georgia), Monuments of Old Georgian Hagiographic Literature, I (V-X centuries), Tbilisi 1963 (in Georgian).

Ostepashvili L., Illustration of Psalm 41 from Ateni Sioni Relief, Fine Art and Religion, №4, Tb. 2009.

Surguladze I., Symbolics of Georgian folk ornaments, Science, Tb. 1986;

Surguladze I., Mythos, Cult, Ritual in Georgia, Tb. 2003.

G. Chubinashvili, Georgian Art History, T-I, Tb., 1936.

Virsaladze E., Georgian Hunting Epos (Cycle of Perished Hunter), Metsniereba, Tb., 1964.

Khidasheli M., Ritual and symbol in archaic culture, Tb. 2005.

The life of Kartli (according to all the basic manuscripts written by S. Kaukhchishvili), T. I, Tb. 1955.

Ancient Metaphrastic Collection, Readings from September, Martyrdom of Saints Eustace and Theophiste and of Their Children [224v], Metsniereba, 1986 (in Georgian). 
Aubert M., La sculpture Française au moyen âge, Paris, 1946,.

Boinet A., Saint Hubert Iconographie et pèlerinage, no 14, Paris, c1959.

Baleau S., Les sources de l'histoire de Liège au Moyen Age, Etude critique, T. I, Bruxelles, 1903.

Biographie nationale, publiée par l' Académie royale des sciences, des letters et des Beaux-arts de Belgique, IX, pp. Bruxelles, 1897, 591.

Bibliotheca Hagiographica Latina, Soc II Bollandiani, Bruxelles, 1911.

Collins P., Introduction and The Art of Ashurbanipal, Assyriian Palace Sculptures, The Trustees of The British Museum, 2008.

Coumoussi A., Une representation rare de la vision de Saint Eustache dans une église grecque du XIIIe siècle, Cahiers Archeologiques, Picard, 1985. Denis M., la Légende de Saint Hubert 1896-1897, Paris, c1999.

Feldman M., Art and Imperialism in the Ancient Near East, History of Art and Near Eastern Studies, UCB, 2010.

Grotoskwski P.L., Arms and Armour of The Warrior Saints, Tradition and Innovation in Byzantine Iconography (843-1261), 2009, Brill NV.

Insights and Interpretation, Edited by Colum Hourihane, Princestone Universuty, New Jersey 2002.

Kurth G., Les premiers siècles de l'abbaye de Saint-Hubert, Bulletin de la Commission royale d'Histoire, Année 1898, N8.

Lanzi F.G., Saints and Their Symbols, Minnesota 2004.

Male É., l'Art religieux du XIIIe siècle en France, Étude sur l'iconographie du moyen âge et sur ses sources d' inspiration, Paris, 1898.

Nassar M., The art of decorative mosaics (Hunting scenes) from Madaba Area during Byzantine period (5 $5^{\text {th }}-6^{\text {th }} c$. Ad), Mediterranean Archeology and Archaeometry, Vol 13, N-1, Greece 2013.

Oman Ch., The Dark Ages 476-918, London 1914.

Salvandy M., Eglise Saint Evstache a Paris, Paris, c1850.

Saltykov A.A., La vision de saint Eustache sur la stele de Tsebelda, Cahiers Archeologiques, Picard, 1985.

Starr B.D., Dictionary of Saints, 2013.

Tanabe K., ICONOGRAPHY OF THE ROYAL-HUNT BAS-RELIEFS AT TAQ-I BUSTAN, Bulletin of the Okayama Orient Museum, vol. XIX 1983.

Thierry N., Un problem de continuitè ou de rupture. La Cappadoce entre 
Rome, Byzance et les Arabes, Comptes rendus des séances de l'Académie des Inscriptions et Belles-Lettres, 121 année, N1, 1977.

Thierry N., La basilique Saint-Jean-Baptiste de Çavuşin (prononcer Tchavouchine), Cappadoce, Bulletin de la Société nationale des Antiquaires de France, Année, 1974.

Vasiliki V. Mavroska Fachbereich Sprach, ADAM AND EVE IN THE WESTERN AND BYZANTINE ART OF THE MIDDLE, AGES, Frankfurt, 2009.

Velmans T., Léglise de Zenobani et le thème de la Vision de Saint Eustache en Géorgie, Cahiers Archeologiques, Picard, 1985.

Voragine J.D., La Légende dorée, trad. par A. Boureau, M. Goullet, L. Moulinier, Paris, Gallimard, coll. « La Pléiade », 2004.

La légende Dorée, Traduite en Français par L'abbé J.B.M. Roze, Édouard Rouveyre, Éditeur, Paris, MDCCCII, 2004.

Reames, Sherry L. The Legenda Aurea: A Reexamination of Its Paradoxical History (Madison: University of Wisconsin Press) 1985.

La Légende dorée (Legenda aurea, vers 1261-1266), trad. sous la dir. d'Alain Boureau, Paris, Gallimard, coll. « La Pléiade », 2004.

Jacques Le Goff: In search of sacred time. Jacobus de Voragine and The Golden Legend. Princeton 2014.

Werness H.B., The Continuum Encyklopedia of Annimal Symbolism in Art, New York 2006.

Аладашвици Н., Монументацъная скулпътура Грузии, сиужетные релиеф V-XI веков, искусство. 1977;

Салтыков А., Видение св. Евстафия Плакиди, рельефные иконы из Цебелды, Искусство христианского мира, Москва1996.

Ворагинский И., Золотая мегенАа. Т. 1. / Вступ. статья и коммент. И.В. Кувшинская. Пер. с мат. И.И. Аникьев, И.В. Кувшинская. - М.: Издательство Францисканцев, 2017.

Уварова А.С., Христианская Символика, I, Символика АревнеХристианскаго Периода, Москва, 1908.

http://www.hampshire-history.com/series/south-east-hampshirechurches/ - 15.05.2018.

https://www.italyheritage.com/traditions/calendar/january/17-sant-antonio.htm - was checked 2.08.2018. 


\title{
Iconographic Variations of St. Eustace Hunting Composition in the Medieval Georgian and French Sculpture
}

\begin{abstract}
The theme of hunting occupies an important place in a diverse iconographic repertoire of relief sculpture in medieval Christian art. Hunting compositions of St. Eustace were very popular both in Eastern and Western Christian arts.

We find relief scenes with images of hunter-horsemen in different forms and interpretations in continuity from the VI-VII th to the XVI ${ }^{\text {th }}$ centuries in Georgia. Georgian Christian art presents a specific visual representation - a hunter and its victim - which is mainly represented in St. Eustace Placida's compositions.

Hunters and victims, archers are present in Western European art, especially in the XII ${ }^{\text {th }}-\mathrm{XVI}^{\text {th }}$ centuries France. But here, along with Placida's hunting, episode of St. Hubert's hunting is also relevant. The scene of the vision of St. Hubert narrated in literary sources is similar to that of the vision of St. Eustace. Iconographic schemes of the compositions depicted on the cathedrals are also analogous, with slight differences.

It is worth of note that various approaches have been formed in the artistic and stylistic resolution of the compositions of St. Eustace due to different historical conditions and local traditions.
\end{abstract}

Keywords: Iconography, Medieval Art, Hunting Scenes, Sculpture.

\section{Сцены охоты Св. Евстафия ПиакиАы в средневековых грузинских и французских рельефах}

\section{Абстракт}

В разнообразном иконографическом репертуаре рельефных скульптур средневекового христианского искусства тема охоты занимает значитемьное место. То же самое можно сказать и о кавказском христианском искусстве, но композиции охоты св. Евстафия Плакиды в рельефных скульптурах сохранимо грузинское искусство. Святой Евстафий пользовался популярностью и в западноевропейском, особенно, во французском христианском искусстве. ГАавная тема настоящей статьи - грузинские и запаАноевропейские рельефные образцы, так как в обоих в среАневековом христианском искусстве большое внимание уАелено сюжетам, связанным со Св. Евстафием ПлакиАой. 
Сцены охоты Св. Евстафия в разных формах и интерпретациях встречаются в Грузии почти во все века, начиная с VI-VII и до XVI века.

Во Франции сцены охоты ПкакиАы встречаются в XII-XVI веках, и паралмельно актуальна охота Святого Губерта. Рассказанная в китературных источниках сцена явления Губерта подобна сюжету о явлении Св. Евстафия. Аналогичны, с небольшими размичиями, и иконографические схемы изображенных на храмах композиций.

В настоящей статье рассмотрены распространенные в среАневековом грузинском и французском искусстве сцены охоты Св. Евстафия и Св. Губерта. На основании иконографического, стилистического и смыслового анализа найденных образцов мы постараемся сгруппировать подобные композиции, выделить их основные характеристики и свойства.

Комплексное изучение материала представит грузинские рельефные скульптуры в широком, географическом контексте и в контексте истории мирового искусства.

Узмовые слова: иконография, среАневековое искусство, сцены охоты, скульптура

Nino Goderdzishvili, PhD Student

Shota Rustaveli Theatre and Film Georgian State University

Tbilisi, Georgia

niniagoderdzishvili@gmail.com 